C. Clacuaction. Quodoc Can

Q.2. zymule

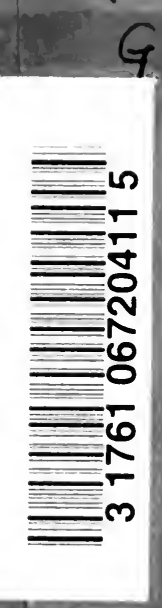

LIST OF PUBLICATIONS

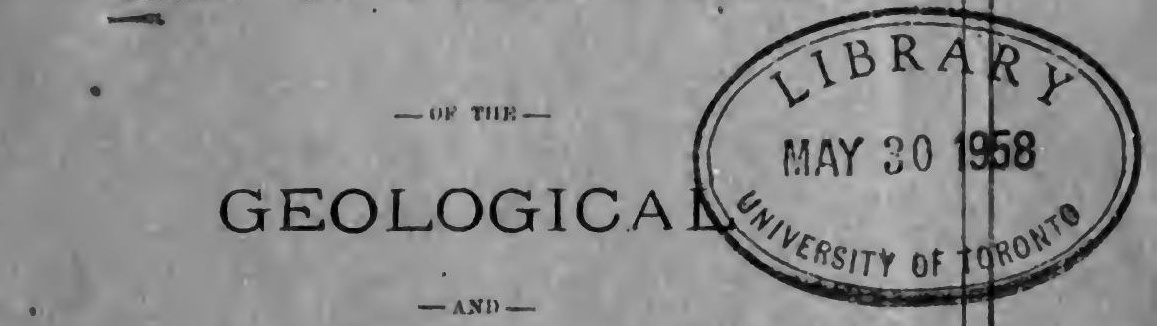

NATURAL FISTORY SURVEY OF CANADA.

MUSEUM, OFFICES AND LIBRARY:

SUSSEX ST., OTTAWA.

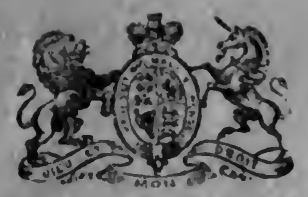

Printed by molean, Roger \& Co. Ottawa. 



\title{
LIST OF PUBLICATIONS
}

\author{
-arm- \\ GEOLOGICAL \\ $-\mathrm{AND}-$ \\ NATURAL HISTORY SURVEY \\ OF CANADA.
}

MUSEUM, OFFICES AND LIBRARY:

SUSSEX ST., OTTAWA.

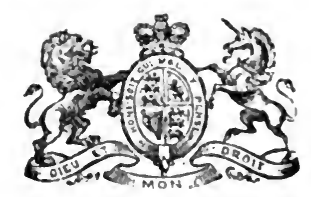

Printed by mclean, Roger \& Co., Ottawa.

1884. 


\title{
GEOLOGICAL
}

AND

\section{NATURAL HISTORY SURVEY}

of

\author{
C A N A D A
}

\section{DIRECTOR :}

ALFRED R. C. SELWYN, LL.D., F.R.S., F.G.S., \&c.

\section{ASSISTANT DIRECTORS :}

ROBERT BELL, M.D., LL.D., F.G.S., \&c., FieLd Geologist.

GEORGE M. DAWSON, D.S , A.R.S.M., F.G.S. , \& C., Field Geologist.

J. F. WHiteaves, F.G.S., F.R.S.C., Paleontologist and Zoologist.

G. Christian hoffman., F. Inst. Chem., Chemist and Mineralogist.

\section{LIBRARIAN :}

JOAN THORBURN, A.M., LL.D. 


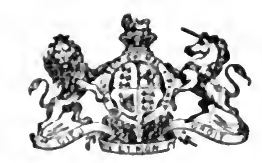

\section{VICTORIA.}

\section{CHAP. 9.}

An Act to make better provision respecting the Geological and Natural History Survey of Canada and for the main. tenance of the Museum in connection therewith.

\section{[Assented to 28th April, 1877.]}

ER Majesty, by and with the advice and consent of the Senate and House of Commons of Canada, enacts as follows :-

1. The Minister of the Interior shall continue to have the control and management of the Geological Survey of Canada, and there shall be a branch of the Department of the Interior known as the Geological Survey Branch, which shall, under the control of the Minister, take cliarge of and conduct the Geological Survey of the several Provinces and Territories of the Dominion.

2. The objects and purposes of the survey and muscum shall be, to elucidate the geology and mineralogy of the Docninion, and to make a full and scientific examination of the various strata, soils, ores, coals, oils and mineral waters, and of its recent fauna and flora so as to afford to the mining, metallurgical and other interests of the country, correct and full information as to its character and resources.

3. It shall be the duty of the persons in charge of the said survey:-

1. To collect, classify and arrange such specimens as may be necessary to insure a complete and exact knowledge of the mineralogical resources of the several Provinces and Territories of Canada; to carry on palaontological investigations, to study and report upon the fauna and flora of the Dominion, and to make such other researches as will best tend to ensure the carrying into effect the object and purposes of this Act;

2. To continue to collect the necessary materials for a Canadian museum of natural history, mineralogy and geology ;

3. To report from time to time, in such manner and form as the Minister may direct, their proceedings under this Act, and to furnish proper maps, diagrams, drawings and collections of specimens to illustrate the same.

4. The Director of the Geological Survey shall, as soon as may be after the close of each calendar year, make a full report to the Minister, of the proceedings and work of the Survey for the year, and the results thereof, 
in such manner and form, and with such details, maps, diagrams and drawings as may be requisite to elucidate the same; and the Minister shall cause the same to be laid before Parliament, with such remarks, explanations and recommendations as he may think proper.

5. The Governor in Council may, from time to time, appoint a suitable person, to be the Director of the Geological Survey, with such assistants as may be necessary to carry out the provisions of this Act, and with such salaries or remuneration as the Governor in Council may determine; provided that such salaries shall be subject to the approval of Parliament.

6. The Director and persons appointed to permanent positions in the Geological Survey Branch of the Department of the Interior, shall be considered as being within the provisions of the Act thirty-third Victoria, chapter four, to provide for the superannuation of persons employed in the Civil Service, in certain cases.

7. The Governor in Oouncil may, whenerer he may think fit, direct the removal of the museum, and the officers and others connected with the Feological Survey Branch of the Department of the Interior, to the City of Ottawa.

8. The museum shall be opened to the public from ten a.m. until four p.m., Sundays excepted, and shall be furnished with such books, instruments and apparatus as may be necessary for scientific reference, and for the prosecution of the survey; and the Governor in Council may, from time to time, cause the enlargement of the museum, and the distribution of duplicate specimens to scientific, literary and educational institutions in Canada and other countries.

9. For the purpose of obtaining an accurate basis from which the geological and topographical features of the country may be ascertained, and for the purpose of connecting together local and partial surveys, the Director of the Geological Survey shall cause such topographical, geographical or other measurements or observations to be made, and monuments or marks to be placed, as may be deemed necessary for this purpose.

10. All railway and canal companies over which the Parliament of Canada has jurisdiction, shall, if incorporated after the passing of the Act thirty-first Victoria, chapter sisty-seven, furnish to the Geological Survey, without charge, certified copies of all plans and sections of their surveys; and all such companies theretofore incorporated, shall furnish such plans and sections upon the demand of the Director of the Geological survey, and at the cost of the Department.

11. Persons employed in one branch of the Department may be directed by the Minister to perform any duty in or with respect to any other branch.

12. This Act shall ccme into force upon, from and after the first day of July, one thousand eight hundred and seventy-seven; and all furmer Acts respecting the Geological Survey of Canada shall then be repealed, except only as to rights acquired under or offences against the same. 


\section{THE PUBLICATIONS}

OF THE

\section{GROLOCGCALL AND NATURALL HISTORY SURVVY OP CANADA.}

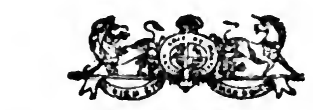

REPORTS OF PROGRESS.

Report of Progress to 1843. Published in both English and French, Montreal 1845. pp. 159. Out of print.

This volume contains the first of the regular Reports of Progress published after the appointment of Logan as Provincial Geologist. It is premised by "Remarks on the mode of making a Geological Survey of Canada," and by a short "Preliminary Report" containing general observations on the Geology of Canada and the adjacent States. The Reports proper are by Logan and Alexander Murray, then Assistant Provincial Geologist, and relate chiefly to the geology of portions of Western Canada. Logan's celebrated section of the measures at the Jogg:ns on the Bay of Fundy is iacluded as an Appendix, and occupies 59 pages.

Report of Progress for 1884. Published in English and French, Montreal 1846. pp. English 110, French 119. English out of print.

Price of French copies, 50c.

Reports by Logan and Murray on the Geology of portions of the Gaspe Peninsula, with an Appendix including a section of the Coal Measures on the Bay Chaleur, New Brunswick, and a number of other sections.

Report of Progress for 1845-46. Published in English and French, Montreal 1847. pp. English 125, French 137. Out of print.

Contains a Report by Logan on the Geology of the Ottawa and some of its Tributaries, and one by Murray on the Gaspé Peninsula. An Appendix by T. S. Hunt gives a list of mineral springs occurring near the Ottawa and its tributaries, and analyses of a few ores, \&c. 
Report of Progress for 1846-47. Published in English and French, Montreal 1847. pp. English 66, French 70. Out of print.

Contains the following Reports by Logan and Murray:-

LogaN-On the Geology and Economic Minerals of Lake Superior.

MURray-On the Geology of the Kaminitiquia and Michipicoten Rivers.

APPENDIX - Containing Statistics of Copper-mining and Coppersmelting in Great Britain.

Report of Progress for 1347-48. Published in English and French,

Montreal 1849. pp. English 165, French 171. Out of print.

Contains Reports by Logan, Murray and Hunt.

LOGAN-On the Geology of portions of Lower Canada, more particularly of the Eastern Townships.

Murray-On the North Coast of Lake Huron.

Hont-On Various Minerals and Mineral Waters.

Report of Progress for 1848-49. Published in English and French,

Toronto 1850. pp. English 65, French 70. Out of print.

Contains the following Reports:-

MorraY - On the Geology of parts of the Coast of Lake Huron, the Spanish River, \&c.

HUnT-On Minersl Springs, Ores, \&c.

Report of Progress for 1849-50. Published in English and French,

Toronto, 1850. pp. English 115, French 120. Out of print.

Contains the following Reports:-

LoGAN-On the Geology of portions of Lower Canada, both North and South of the St. Lawrence.

Hont-On Soils, Peat, Asphaltum, Mineral Springs, \&c.

APPENDix-Catalogue of some of the Economic Minerals and Deposits of Canada.

Report of Progress for 1850-51. Published in English and French,

Quebec, 1852. pp. English 54, French 56. Out of print.

Contains the following :-

LogaN-On the Gold of the Chaudière Region.

Murray-On the Geology of the Western Peninsula.

Hont-On Various Minerals and Mineral Waters.

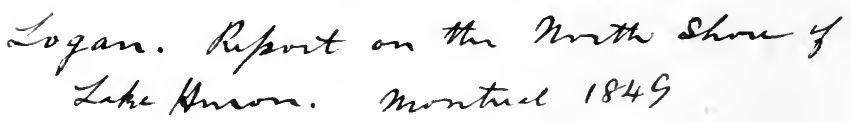


Report of Progress for 1851-52. Published in English and French, Quebec, 1852. pp. English 121, French 129. Out of print.

Coatains the following :-

Logan-On the Geology of the Counties of Beauharnois and the Lake of Two Mountains; on various Economic Minerals, and on the Industrial Exhibition of 1851 (London). A catalogue is given of the Canadian Minerals shown at this Exhibition.

Murray-On the Geology of the Region between the Ottawa, the St. Lawrence and the Rideau.

Howt-On the Examination of a number of Minerals, Soils, Mineral Waters, \&c.

Report of Progress for 1852-53. Published in English and French

Quebec, 1854. pp. English 179, French 197. Out of print.

Cpp L Contains the following :-

Logan-On the Geology of the North Shore of the St. Lawrence, between Montreal and Cape Tourment, and on Miscellaneous Economic Minerals.

Morray-On the Geology of the Region between Kingston and Lake Simcoe.

Hunt-On Mineral Waters, Various Minerals, Ores, \&c.

Report of Progress for the years 1853-54-55-56. Published Toronto, 1857. In English and French. pp. 494.* With a large 4to. A tlas of Maps.

Price with A tlas, $\$ 4.00$.

This volume contains Reports by Logan, Murray, Richardson, Billings and Hunt, on subjects enumerated below.

LogaN-On the Laurentian Rocks of Grenville, Chatham, St. Jerome \&c., and the Economic Materials found in them.

MCrRAY-Reports for 1853-56 inclusive, on the Topographical and

Geological Features of the Region between the Ottawa River and Georgian Bay, as well as North of Lake Huron.

RICHARDSON-Report for 1856 on the Island of Anticosti, and the Mingan Islands.

Billings-Report for 1856 on Fossils from Anticosti, and on New Fossils from the Silurian of Canada.

*Unless both are given, the number of pages always refers to the English edition. 
HUNT-Reports for the years 1853-56 inclusive, containing numerous Analyses of Minerals, Rocks, and Mineral Waters, and observations (Report for 1855) on the Metallurgy of Iron, the Manufacture of Salts from Sea-water, \&c.

The volume contains a Map illustrating the distribution of the crystalline limestones in the Grenville Region; a reduced map of $\mathrm{Mr}$. Murray's Explorations, and a Map of Anticosti. The Atlas contains twenty sheets by Mr. Murray and two sheets by Sir W. E. Logan, embracing the results of their Surveys of the Region between Lake Huron and the Ottawa River.

Report of Progress for the Year 1857. Published Toronto, 1858. In English and French. pp. 240. Five Maps.

This volume contains the following Reports :Price, 50c.

LOGAN-Remarks relating chiefly to the succeeding Reports.

MURray-On the Coast at the mouth of French River, Georgian Bay; on Echo Lake and its environs, and on the Limestone of Bruce Mines.

Riohardson-On part of the Gaspé Peninsula from Magdalen River to Gaspé Bay, and on Lake St. John.

Bril-On the Fauna of portions of the Lower St. Lawrence, the Saguenay, Lake St. John, \&c.

HALL-Descriptions of Canadian Graptolites.

BiLuras-0n the Black River Limestone and the Limestone of Galt Also descriptions of various Fossils.

Hunt-On Dolomites, Limestones, Fish Manures, \&c.

Astr (Lieut. E. D.)-On the Longitude of some of the principal places in Canada, as determined by Electric Telegraph in the years 1856-57.

Report of Progress for the Year 1858. Published Montreal, 1859. In English and French. pp. 263. Contains three Maps and a Section.

This volume contains the following Reports:-

Price, 75c.

LoGAN-On the Distribution of the Laurentian Limestones, and of the Drift, in the Grenville Region. Also on the Ramsay Lead Mine, the Acton Copper Mine, and Miscellaneous Economic Minerals.

MURray-On the country between the Thessalon River and Lake Huron, and between the Thessalon and the Mississagui.

Richardson-On the Geology of a portion of the Gaspé Peninsula, in. cluding an examination of the Coast from the Marsouin River to Rivière du Loup. 
Hont-On Intrusive Rocks, Minerals from Silurian Rocks, and on the History of Magnesian Limestones.

An appendix to this volume includes the following:

Levels of the River Rouge, \&c.

Localities of Copper Ores in the Silurian Rucks of Lower Canada.

Localities of Copper Ores in the Huronian Rocks, Mississagui River.

Catalogue of Animals collected by Mr. D'Urban in the Counties of Argenteuil and Ottawa.

Catalogue of Animals and Plants collected by Mr. R. Bell on the South-East side of the St. Lawrence, from Quebec to Gaspé.

Geology of Canada; Report of Progress of the Geological Survey from its commencement to 1863. With an $A$ tlas of Maps and Sections. Published 1863 ; in English and in French. Large 8 vo. pp. 983. Includes the more important facts published in all the preceding Reports. (For contents of Atlas, which may be had separately, see p. 17.)

Price of the Report: Cloth, $\$ 5.00$; Atlas, cloth, $\$ 2.50$.

"The style in which this work has been got up, the precision of the drawing, and the accuracy of the woodcuts, may almost challenge comparison with the execution of similar productions on this side of the Atlantic. There bas been a steady persistance in the conduct of this remarkable survey, honourable alike to the successive Governments that have encouraged it, and to the officers who have carried out the work. No other Colonial Survey has ever yet assumed the same truly national character; and the day may come-if ever the "Imperial Colony" shall claim and obtain independence-when the scientific public of a great nation, looking back upon the earlier dawnings of science in their land, shall regard the name of Logan, native born, with the same affectionate interest with which English geologists now regard the names of our great geological map makers, William Smith and De la Beche."-London Saturday Review.

"This large octavo, of 983 pages, illustrated with 498 woodcuts, and to be accompanied by an atlas of maps and sections, presents a condensed view of the work of the Canadian Survey from its commencement in 1863 . It gives the results of the com- bined labours of Sir W. E. Logan, Mr. Marray, Dr. Hunt and Mr. Billings, a staff not to be surpass$\epsilon d$ either in ability or energy, and aided also by several able assistants, of whom Mr. Richardson and Mr. Bell stand first. The value of the work to Canada can scarcely be over-estimated. It must be regarded as of vast importance, whether we consider readers abroad or at home, whether we consider scientific objects purely or those which are practical. Its mechanical execution is an evidence if the progress of the arts among us. Its publication to the world is a proof of the interest taken in science in this country, and of the enlightened patronage afforded by the Government to such investigations, and: at the same time, of the immense value of our mineral resources, as well as of the extent to which they have already been made arailable. It gives, for the first time, to geologists abroad the means of making themselves thoroughly acquainted with the geology of this country; and it thus places Canada on a level with those older countries whose structure has been explored, and the knowledge of it made the common property of the world."-Canadian Naturalist. 
Report of Progress, 1863-66. Published Ottawa, 1866. In Englieh and French. One vol. large $8 \mathrm{vo}, \mathrm{pp}$. 321. Out of print.

This volume contains the following Reports :-

LOGAN-Summary Report of Geological Investigations.

RICHARDson-On the Geology of the Quebec Group in the Eastern Townships.

*Michel-0n the Gold Region of Lower Canada.

Price, 25c.

*Hont-On Gold Assays of Quartz from Eastern Canada, Mineralogy of Gold Veins, and method of Gold-working. Price, 25c.

MaCfarlane-On the Geology and Economic Mine rals of portions of the County of Hastings.

Macrarlane-On the Laurentian, Huronian and Upper Copper-bearing Rocks of Lake Superior. With an Appendix on the Rocks and Cupriferous Beds of Portage Lake, Michigan.

BeLL-On the Geology of the Grand Manitoulin Island.

HUNT-On the Geology and Mineralogy of the Lauren tian Limestones; on Petroleum and Salt; on the Porosity of Rocks; and on Peat and its Applications.

Appendix-List of Copper Localitics in Eastern Canada.

Report of Progress, 1866-69. Summary of Geological Investigations,

by Sir W. E. Logan, F.R.S., \&c. Published Ottawa, 1869. pp. 9.

Report of Progress from 1866 to 1869. Published Montreal, 1870.

In English and French. Large 8vo, pp. 475. The English edition is now out of print.

Price of French edition, \$2.00.

This volume contains the following Reports:-

"Logan and Hartley-Reports on part of the Pictou Coal Field.

With a coloured Geological Map.

Price, with an Appendix on Coal and Iron Ores, $\$ 1.00$.

BELL-On the Geology of the Manitoulin Island Gronp.

Richardon-On the Region South of the St. Lawrence, between the

Chaudière River and the Temiscouata Road. With a coloured Geological Map.

*Reports and maps marked thus can be procured separately at the prices attached. 
*Vannor-On the Geology of portions of Hastings, Peterborough and Frontenac Counties, Ontario. With a coloured Geologicsl Map.

Price, 60c.

ROBB-On the Geology of a part of New Brunswick. With a SketchMap.

*Hont-On the Goderich Salt Region. Price, 25c.

"hunt-Notes on Iron and Iron Ores. Price, 25c.

Richardson-Report for 1869 on the North Shore of the Lower St. Lawrence.

"Beld - On the Geology of the North-West Coast of Lake Superior and the Nipigon District. Illustrated by a topographical SketchMap.

Price, 75c.

*Harthey-Report on the Coals and Iron Ores of Pictou Connty, Nova Scotia; being an Appendix to Reports on the Picton Coal Field. (Vid. ante.)

Price, 60c.

Bartue-Notes on coal from Springhill Coal Field. pp. 5.

*BeLL, J., M.D.-Appendix on the Plants of the Manitoulin Islands.

Price, 25c.

Postcript by Sir W. E. Logan, addressed to Alfred R. C. Selwyn.

Noтt.- Op to 1860 the Geological Reports were printed as Appendices to the Journals of the Legislative Assembly, in English and French. The Appendices in which they are to be found are as tollows:-

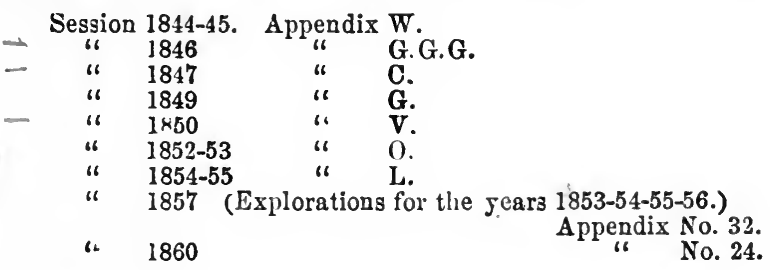

SPECIAL REPORTS, \&c.

-Remarks on the Mining Region of Lake Superior, addressed to the Committee of the Executive Council; and Report on Mining Locations claimed on the Canadian Shores of the Lake, addressed to the Commissioner of Crown Lands. By W. E. Logan. Published Montreal, 1847. pp. 31.

Price, 10c.

Esquisse Geologique du Canada, pour servir à l'intelligence de la Carte géologique et de la Collection des Minéreaux économiques envoyces a l'Exposition Universelle de Paris, 1855. Par W. E. Logan et T. Sterry Hunt. Paris, 1855. pp. 100. 
* Descriptive Catalogue of a Collection of the Economic Minerals of Canada, and of its Crystalline Rocks. Sent to the London International Exhibition for 1862. Published Montreal. Large 8vo, pp. 83.

Price, 25c.

* Notes on the Gold of Eastern Canada, being a Reprint of portions of various Reports of the Geological Survey of Canada, from 18481863. Published Montreal, 1864. pp. 40.

*Pretroleum-Its Geological Relations considered with especial reference to its occurrence in Gaspé. With a Geological Map by R. Bell of a portion of Gaspé. By T. Sterry Hunt. Published Quebec, 1865. pp. 33.

Price, 50c.

*Canada-A Geographical, Agricultural and Mineralogical Sketch. By T. Sterry Hunt. Published. Quebec, 1865. pp. 33.

Price, 25c.

*Esquisse Geologique du Canada, suivie d'un Catalogue Déscriptif de la Collection de Cartes et Coupes géologiques, Livres imprimés, Roches, Fossiles et Minéreaux économique enroyées a l'Exposition Universelle de 1867. Par T. Sterry Hunt. Paris, 1867. pp. 72.

Price, 50c.

*Reports on the Gold Region of the County of Hastings. By Dr. T. Sterry Hunt and Mr. A. Michel. Transmitted by Dr. Hunt to the Hon. Commissioner of Urown Lands, January 29, 1867. Published Montreal, 1867. pp. 11.

Price, 10c.

*Report on the Gold Region of Nova Scotia. By T. Sterry Hunt. Published Ottawa, 1868. Large 8vo, pp. 48.

Price, 25c.

\section{DESCRIPTIONS AND FIGURES OF CANADIAN ORGANIC REMAINS.}

Decade 1-Descriptions of twenty-nine species of Lower Silurian Fossils. By J. W. Salter. Illustrated with ten steel plates. Large 8vo, pp.

47. Published Montreal, 1859.

Price, $\$ 1.00$.

Decade 2-A Monograph of the Graptolitidæ of the Quebec Group. By Prof. James Hall. Illustrated with twenty-nine steel plates. Large 8vo, pp. 151. Published Montreal, 1865. 
Decade 3-Monographs of Lower Silurian Cystideæ, and Asteriadæ. By E. Billings. Description of the genus Oyclocystoides. By J. W. Salter and E. Billings. Monograph of the Palæozoic Bivalvo Entomostraca of Canada. By Rupert Jones. Illustrated with eleven lithographed plates and numerous wood cuts. Large 8vo, pp. 102. Published Montreal, 1858.

Price, $\$ 1.00$.

Decade 4-Monograph of the Lower Silurian Crinoideæ. By E. Billings. Illustrated with ten lithographed plates and numerous wood cuts. Large 8vo, pp. 72. Published 1859.

Price, $\$ 1.00$.

Catalogues of the Silurian Fossils of the Island of Anticosti, with descriptions of some new geners and species. By E. Billings. Published Montreal, 1866. pp. 93.

Price, 25c.

Paløozoic Fosslls, containing descriptions and figures of new or little known species of Organic Remains from the Rocks of the Silurian and Devonian Formations. By E. Billings.

Vox. I-1861-65-Published Montreal, 1865. Illustrated by 399 wood cuts. Large 8 ro, Oloth. pp. 426.

Price, \$2.50.

\section{MAPS.}

Geological Map of Cansda and the adjacent Regions, including the other British Provinces, and parts of the United States. By Sir W. E. Logan, F.R.S., \&c. Published 1866. Scale 25 miles to one inch.

$\begin{array}{cr}\text { Price, in sheets. ................................... } \$ 1800 \\ \text { " mounted on rollers........................... } \\ \text { " } 2450 \\ \text { in portfolio, portable shape..... } & 2500\end{array}$

The Geology of Canada (Quebec and Ontario) is derived from the results of the Canadian Geological Burvey; that of the other Provinces from the labours of Dr. J. W. Dawson, Professor Robb, Jukes, and others; while that of the United States is compiled under the authority of Professor James Hall, from various sources mentioned in the Atlas accompranying the "Geology of Canada."

This truly great and beautiful Map will at once recommend itself to all lovers of Geological Science in America. It consists of eight sheets, each $24 \times 20 \frac{1}{2}$ inches, and, when mounted on rollers, measures $8 \mathrm{ft}$. by $3 \mathrm{ft}$. 7 in. It is engraved on steel, in the best style, and is coloured by band in 33 colours, showing the different formations. The territory mapped extends from Labrador on the East, to the Red River on the West, and from Hudson's Bay on the North, to Northern Virginia on the South. Besides the Geology of the British Provinces (the main object of the Map), the Geology of the Northern United States is fully shown; and it is as completely a Geological Map for the States of New York, Pennsylvania, Ohio, Indians, Illinois, New Jersey, Vermont, Michigan, Missouri, Iowa, Wisconsin and Minnesota, as it is for Canads. The Coal Regions are shown with precision from Oape Breton to Missouri. 
"We have at length the pleasure of announcing the appearance of this important and longlooked for contribution to American geology. The legend of the Map informs us that the geological details for Canada, comprising the former Provinces of Upper and Lower Canada (now Ontario and Quebec) are furnished by the Geological Survey under the direction of Sir William E. Logan. He has himself compiled the geology of the various States of the Onion, under the supervision of Prof. Hall, from various sources which are mentioned in detail in the pre-

face to the Atlas of the Geology of Canada (published in 1865) where he tells us that this portion of the work was done 'with the approval of Prof James Hall, who has freely placed all his materials at the disposal of the compiler, and aided by his intimate personal knowledge of the geology of a greater part of the region represented.' For the geology of the Provinces of Now Brunswick, Nova Scotia and Newfoundland, also, the most authentic printed and manuscript maps were consulted, as described in the Atlas just referred to."-Silliman's Journal."

An Atlas to Accompany the Report of Progress for 1853-56, containing twenty-two folio maps of various Lakes and Rivers between Lake Huron and the River Ottawa. Published Toronto, 1857.

Large 4to, half bound. Price, with the Report, $\$ 4.00$.

The Maps are on a scale of one inch to a mile and lithographed on sheets of twenty-two by thirty-three inches. They are as follows:-

I-Maps showing Explorations on the North Shore of Lake Huron and thence Eastward to the Ottawa.

1. Spanish River.

2. Spanish River, with White-Fish Tributary and White-Fish Lake; White-Fish River with Lakes Panache and Lavase, and Round Lake.

3. Mouth of the White-Fish River, and Coast of Lake Huron.

4. Wahnapitæping Lake and Wahnapitæ River, with Maskanonge Lakes and River.

5. Wahnapitæ River.

6. Wahnapitæ River, with Channels and Mouths of French River.

7. Sturgeon River.

8. Sturgeon River and West end of Lake Nipissing.

9. French River.

10. East end of Lake Nipissing and Nahmanitigong River, with part of Mattawa River.

11. Mattawa River and part of Ottawa River.

II-Maps showing Explorations between the East Shore of Lake Huron and the Ottawa River.

12 and 13. Meganatawana River, with miscellaneous Lakes. 
14 to 18 inclusive. Muskoka and Petewahweh Rivers, and numerous Lakes.

III-Maps of Bonne-chère, Madawaska and Shawaghkong Rivers and sources of the Ottonabee.

19. Bonne-chère River with Mud Lake and Clear Lake.

20. Bonne-chère River with Golden and Round Lakes, and Little Madawaska River, Lake Kamaniskaik, and Madawaska River, and South-west Branch or Shawashkong River.

21. Shawashkong River, with Kaijick Manitou and Papineau Lakes.

22.: Drag Lake, Kah-shah-gah-wigamog Lake, Gull River, Gull Lake and Balsam Lake.

An Atlas of Maps and Sections to Accompany the Report of Progress of 1863-Published Montreal, 1865. Large 8vo, Cloth.

Price, $\$ 250$.

This Atlas contains the following Maps and Sections:-

* Coloured Geological Maps of portions of the British Provinces and the United States.

Price, $\$ 1.50$.

*Coloured Majs showing the distribution of the Laurentian Rocks in parts of the Counties of Ottawa, Terrebonne, Argenteuil and Two Mountains. Scale 7 miles to 1 inch.

$$
\text { Price, 25c. }
$$

*Coloured Map showing the distribution of the Huronian Rocks between Rivers Bachehwahnung and Mississagui-the typical Huronian Region of Mr. Murray. Scale 8 miles to 1 inch.

Price, 25c.

*Coloured Map showing the distribution of Rocks belonging to the Potsdam, Quebec and Trenton Groups on the East side of Lake Champlain. Scale 2 mules to an inch.

Five uncoloured sections of these Rocks.

Price, 25c.

Uncoloured Map showing the distribution of Limestone Conglomerates in the Quebec Group at Point Levis.

Uncoloured section of these Rocks.

*Map (partly coloured) showing the distribution of various Superficial Deposits between Lake Superior and Gaspé.

Price, 25c.

* Four plates of coloured,Geological Sections illustrating the Geology of Canada.

Price, 10c. each. 
*Map of the Springhill Coal Field, County of Cumberland, Nova Scotia. Scale 1 inch to 1 mile. Price, 25c.

Map of the Grand Lake Coal Field and the Older Rock Formations in Queens and Sunbury Counties, New Brunswick.

The following is a list of Maps accompanying some of the Reports enumerated on the preceding pages.

Report of Progress 1853-54-55-56.

Map showing the distribution of Crystalline Limestones of the Laurentian Series in various Townships between Grenville and Rawdon. Scale 3 miles to 1 inch.

Two Index Maps of Atlas (see p. 16) showing Exploration between Lake Huron and the Ottawa. Scale 10 miles to an inch.

Map of the Island of Anticosti. Scale 9 miles to an inch.

Report of Progress for 1857.

Map showing the;distribution of the Huronian Limestone between Root River and Bruce Mines.

Map showing the distribution of the Laurentian and Lower Silurian Rocks in the vicinity of Lake St. John.

Topographical Map of the Magdalen River.

Report of Progress for 1858.

Map showing the distribution of Crystalline Limestones of the Laurentian Series in the Counties of Argenteuil and Ottawa.

Map showing the distribution of the Haronian Rocks betweed Rivers St. Mary and Mississague.

Map showing the distribution of the Devonian and Silurian Formations in a part of Gaspé. By Robert Bell.

Report of Progress for 1866-68.

* Coloured Geological Map of the Pictou Coal Field, Nora Scotia. Scale 1 inch to a mile.

Price, 30c.

- Coloured Map showing the distribution of Lower Silurian Rocks between the Chaudière and Trois Pistoles Rivers, South of the River St. Lawrence. Scale 8 miles to $l$ inch.

Price, 25c.

*Coloured Map showing the distribution of the Rock Formations in parts of the Counties of Peterborough, Hastings, Addington and Frontenac, Ontario. Scale 4 miles to 1 inch. 
-Sketch-Map of the Oounties of York, Carleton and part of Victoria, New Brunswick. Scale 8 miles to 1 inch.

Price, 25c.

Topographical Sketch-Map showing the Thunder Bay and Lake Nipigon Regions. Scale 4 miles to 1 inch.

NOTE.

In December, 1869, Sir William Logan retired from the Directorship, and was succeeded by the present Director A. R. C. Selwyn.

Report of Progress, 1869-70. Summary of Geological Investigations, by Alfred R. C. Selwyn. Published Ottawa, 1870. pp. 14.

Report of Progress for 1870-71. Published Ottawa, 1872. In English and French, Large 8vo, pp. 351. Price, \$1.25.

This rolume contains the following Reports :-

SeLwYN-Summary Report of Geological Investigations.

Bainay and Mattarw-On the Geology of Sonthern New Brunswick. pp. 228.

Rовв-Supplementary Report on the Geology of North-Western New Brunswick.

SwLwYN-Notes of Observations on the Gold Fields of Quebec and Nova Scotia.

Richardson-On the Geology of the Country North of Lake St. John.

Vennor-Abstract of a Report on the Geology of parts of the Counties of Frontenac, Leeds and Lanark, Ontario.

Brooms-On the Phosphate of Lime and Mica found in North and South Burgess.

BELL-On the Country North of Lake Superior, between the Nipigon and Michipicoten Rivers.

Report of Progress for 1871-72. Published Montreal, 1872. In English $\nmid$ Large 8vo, pp. 154.

Price, $\$ 1.00$.

This volume contains the following Reports:-

Introddotory REPORT OF THE DiRECTOR.

Selwyn-Journal and Report of Preliminary Explorations in British Columbis.

† Published in French in Sessional Documents of the Honse of Commons for 1872, Vol. V., No. 7. The Report bears Number 31. Printed Ottawa, 1873. pp. 156. 
Richardson-On the Coal Fields of the East Coast of Vancouver Island. With a Map of their Distribution. Also a note by Dr. Dawson on Fossil Plants, and Analyses of Coals, \&c., by Dr. Hunt.

BruL-On the Country between Lake Superior and the Albany River. McOdaT-On Exploration of Country between Lake St. John and Lake Mistassini.

Vennor-On the Geology of the Counties of Leeds, Frontenac and Lanark, Ontario; with notes on the gold of Marmora. Accompanied by a Map of the Township of Marmora, showing the position of the Mines now being worked for Gold, and by a Table of Essays by B. J. Harrington.

BAILEY-On Geological Investigations in New Brunswick.

ROBB-Mining and Mineral Statistics.

Report of Progress, 1872-73. Published Montreal, 1873. In English and

French. Large 8vo, pp. 300. With Map and Illustratione.

This volume contains the following Reports:-

Price, \$1.75.

INTRODUCTORY REPORT OF THE DIRECTOR.

SelwYN-Notes of a Geological Reconnaissance from Lake Superior to Fort Garry.

SeLwYN-On the Acadia Iron Ore Deposits of Londonderry, Colchester County, Nova Scotia. With notes on samples of Iron Ore by B. J. Harrington.

Richardson-0n the Coal Fields of Vancouver and Queen Charlotte Islands. With a Map of the former, an Appendix by Dawson (J. W.) on Fossil Plants, another by Billings on Mesozoic Fossils, and a third by Harrington on the Coals of the West Coast.

BeLt-On the Country between Lake Superior and Lake Winnipeg.

MoOdaT-On the Country between Lake Temiscamang and Abbittibbe.

Vennor-On Explorations and Surveys in the Counties of Frontenac, Leeds and Lanark. With a Plan of the Dalhousie Iron Mine.

Bailey and Matthew-On the Carboniferous System of New Brunswick, in the Counties of Queen's, Sunbury, and a portion of York.

ElLs-Operations in boring for Coal with the diamond-pointed steam drill, at Newcastle Bridge, New Brunswick. 
Roвb-On the Coal Mines of the Eastern or Sydney Coal Field of Cape Breton, Nova Scotia.

Harrington-Notes on Samples of Brick Clay from Fort Garry ; Analysis of Serpentine, \&c.

Report of Progress, 1873-74. Published Montreal, 1874. In English and

French. Large 8ro, pp 268. With a Map and Illustrations.

This volume contains the following Reports:-

Price, \$1.50.

INTRODJCTORY RePORT OF THE DiReotor.

SruwYN-Observations in the North-West Territory, on a Journey across the Plains, from Fort Garry to Rocky Mountain House, returning by the Saskatchewan River and Lake Winnipeg. With an Appendix by B. J. Harrington on Western Cosls, \&c.

BeLL-On the Country between Red River and the South Saskatchewan, with Notes on the Geology of the Region between Lake Superior and Red River. With an Appendix by C. Hoffmann on Lignites.

-Richardson-On Geological Explorations in British Columbia.

Price, 25c.

VenNoR-Report of Explorations and Surveys in Frontenac, Leeds and Lanark Counties, with Notes on the Plumbago of Buckingbam, and Apatite of Templeton and Portland Townships, Ottawa County. With Plan of a portion of North Burgess showing position of Apatite Openings.

BARLOW-On the Fxploration and Survey of the Springhill Coal Field, Cumberland County, Nova Scotia. With a Map showing the position of the Springhill Coal Field.

McOdat-On a Portion of the Coal Field of Cumberland County, Nora Scotia.

Roвb-On Exploration and Surveys in Cape Breton, Nova Scotia.

*Harrington-On the Iron Ores of Canada and their Development.

Price, 50c.

-Whitraves-Notes on the Cretaceous Fossils collected by Mr. Jas. Richardson, at Vancouver and the adjacent Islands. With a Lithographed Plate.

Price, 50c.

Report of Progress for 1874-75. Published Montreal, 1876. In Fuglish and French. Large 8vo, pp. 319. With Maps and Illu;trations.

This volume contains the following Reports:-

Introdoctory Report of the Director. 
BatL-On the Country West of Lakes Manitoba and Winnipegosis, with Notes on the Geology of Lake Winnipeg.

BPENCER-On the Country between the Upper Assiniboine River and Lakes Winnipegosis and Manitoba.

Richardson-On Explorations in British Columbia.

BAILEY AND MATTHEW-Summary Report of Geological Observations in New Brunswick.

ELLS-Second Report on the Boring Operations with the Diamond Drill at Newcastle Bridge, Queen's County, New Brunswick.

Euss-On the Iron Ore Deposits of Carleton County, New Brunswick. With a Map showing the Distribution of the Ores.

VenNor-Explorations and Surveys in the rear portions of Frontenac and Lanark Counties, together with Notes on some of the Economic Minerals of Ontario. With a Geological Map of Lanark County and parts of Renfrew and Leeds.

Roвв-Explorations and Surveys in Cape Breton, Nova Scotia. With two coloured Geological Maps, and a Table of Sections of the Measures in the Sydney Coal Field.

Smrn-Observations on the History and Statistics of the Trade and Manufacture of Canadian Salt.

Harrington-Notes on a few Canadian Minerals and Rocks.

Hoffmann-Chemical Contributions to the Geology of Canada.

Report of Progress for 1875-76. Published Montreal, 1877. In

English and French. Large 8vo, pp. 432.

Price, \$2.60.

This volume contains the following:-

Sommary Report of Grologioal Invegtigations, by the Direotor.

Harrington-Biographical Sketch of Sir William Edmond Logan.

Selwy - Report on Explorations in British Columbia. With nine

Illustrations, Sketch-map of Route and three Appendices. I.

By Macoun on the Lower Peace and Athabaska Rivers; II. By

Whiteaves on Fossils collected during the Expedition; and III.

By Le Conte, on Coleoptera.

Macoun-0n the Botany of the country traversed, from the Pacific to

Carleton on the Saskatchewan. With an Appendix containing

a Catalogue of Plants.

Dawsox (G. M.)-Report on Explorations in British Columbia. With five Illustrations and two Sections.

"SCODDER-On the Insects of the Tertiary Beds at Quesnel, British

Columbia. An Appendix to the last. 
ELLs-On Boring Operations in the North-West Territory in the summer of 1875 .

Bell-Report on an Exploration in 1875, between James' Bay and Lakes Superior and Huron.

Barlow (Scotr)-Report of Progress in the Exploration and Survey of the Coal Fields of Cumberland County, Nora Scotia.

BaILey AND MAtTHEW-Report of Geological Observations in Southern New Brunswick.

Flatcher-Report of Explorations and Surveys in Cape Breton, Nova Scotia. With a Section and coloured Geological Map.

Horrmann-Chemical Contributions to the Geology of Canada.

Report of Progress for 1876-77. Published Montreal, 1878. In Eng-

lish and French. Large 8v0, pp. 531. Price, \$2.50.

Sommary Report of Geological Investigations, by the Direotor.

Dawson (G. M.)-Report of Explorations in British Columbia, chiefly in the Basins of the Blackwater, Salmon and Nechacco Rivers, and on François Lake. With seven Illustrations and a coloured Geolcgical Map.

Dawson (G. M.)-Report of a Reconnaissance of Leech River and Vicinity.

*Dawson (G. M.)-General Note on the Mines and Minerals of Economic value of British Columbia, with a List of Localities (Reprinted, with additions and alterations, from the Canadian Pacific Railway Report, 1877). Price, 25c.

Whiteaves-Notes on some Jurassic Fossils collected by, Mr. G. M. Dawson in the Coast Range of British Columbia.

Richardson-Report on the Coal Fields of Nanaimo, Comox, Co. witchan, Burrard Inlet and Sooke, British Columbia. With three Illustrations and a Map.

BeLL-Report on Geological Researches North of Lake Huron and East of Lake Superior.

Hunt-The Goderich Salt Region. (Reprinted from the Transactions of the American Institute of Mining Engineers, Vol. V.)

Vennor-Progress Report of Explorations and Surveys made during the years 1875 and 1876 in the Counties of Renfrew, Pontiac and Ottawa, together with additional notes on the Iron Ores, Apatite, and Plumbago Deposits of Ottawa County. With a coloured Geological Map. 
Matthew-Report on the Slate Formations of the Northern part of Charlotte County, New Brunswick, with a Summary of Geological Observations in the South-eastern part of the same County.

BaILEx AND ElLs-Report on the Lower Carboniferous Belt of Albert and Westmorland Counties, N.B., including the "Albert Shales." With Sections and a coloured Geological Map.

Futcher-Report on the Geology of part of the Counties of Victoria, Cape Breton and Richmond, Nova Scotia. With a coloured Geological Map.

*ScUDDER-Additions to the Insect-Fauna of the Tertiary Beds at Quesnel, British Columkia.

Price, 25c.

Harrington-Notes on Miscellaneous Rocks and Minerals.

*Hofrmans - Chemical Contributions to the Geology of Canada. On Canadian Graphite.

Price, 25c.

Report of Progress, 1877-78. Published Montreal, 1879. In English

and French. Large 8vo, pp. 493. With Maps, Plates, Sections and

Illustrations.

Price, \$2 50.

This volume contains the following :-

Sommary Report of the Operations of the Gelogical Corps, by THE Director.

Additions to the Library.

SeLwXN-Report of Observations on the Stratigraphy of the Quebec Group and the older Crystalline Rocks of Canada.

Dawson (G. M.)-Preliminary Report on the Physical and Geological Features of the Southern portion of the Interior of British Columbia. With five Plates, eight Illustrations and one sheet of Sections.

BeLL-Report on an Exploration of the East Coast of Hudson's Bay. With six Plates and three Illustrations.

BELL-Report on the Country between Lake Winnipeg and Hudson's Bay. With five Plates.

ELls-Report on the Pre-Silurian Rocks of Albert, King's and St. John Counties, Southern New Brunswick.

Matrhew (G. F.)-Report on the Upper Silurian and Kingston (Huronian) of Southern Ncw Brunswick.

MatThew (G. F.)-Report on the Superficial Geology of Southern New Brunswick. With Section of Leda Clay.

Fletcher-Report of Explorations and Surveys in Oape Breton, Nova Scotia. 
Harrimgton-Report on the Minerals of some of the Apatite-bearing veins of Ottawa County, Quebec, with Note on Miscellaneous Rocks and Minerals. With nine Illustrations.

Borrmann - Chemical Contributions to the Geology of Canada.

Report of Progress for 1878-79. Published in Montreal, 1880. In English and French. Large 8vo, pp. 376. With Maps, Plates, Sections and Illustrations.

Price, \$2 50.

This volume contains the following :-

Sommary Report of Geological Investigatons, by the Director.

Dawson (G. M.)-Report on the Queen Charlotte Islands. With Appendices A to $G$. Maps, 3. Plates, 14.

APPENDix A-On the Haida Indians of the Queen Oharlotte Islands.

Appesorx B-Vocabulary of the Haida Indians.

Appendix C-On some Marine Invertebrata from the Queen Charlotte Islands, by Mr. J. F. Whiteaves.

APPendix D-Notes on the Crustacea from the Queen Charlotte and Vancouver Islands, by Mr. S. J. Smith.

APPendix E-List of Plants from the Queen Charlotte Islands, by J. Macoun.

ApPEndx F-Meteorological Observations.

APPENDIX G-Notes on Latitude and Longitude.

Babl-Report on Explorations of the Churchill and Nelson Rivers, and around God's and Island Lakes. With Appendices I. to VII. Map, 1. Plates, 6.

Appendix I-On some Silurian and Devonian Fossils from Manitoba, \&c.

Appendix II-List of Plants collected by Dr. Bell around the shores of Hudson's Bay and along the Churchill and Nelson Rivers in 1877 and 1879.

Appendix III-List of Fresh-water Mollusca from Manituba and the Valley of the Nelson River.

Appsndx IV-List of Lepidoptera from the Nelson and Churchill Rivers and the West Coast of Hudson's Bay.

APpendix V-List of Coleoptera collected by Dr. R, Bell in 1879 on the Nelson and Churchill Rivers.

Appandix VI-List of Birds from the region betwcen Norway House and Forts Churchill and York.

APPENDIX VII-Variation of the Compass. 
Baibey, Matthew and Ells-Report on the Geology of Southern New Brunswick, Counties of Charlotte, Sunbury, Queens, Kings, St. John and Albert.

Homprann-Ohemical Contributions to the Geology of Oanada.

Report of Progress for 1879-80. Published Montreal, 1881. In Eng-

lish and French. Large 8v0, pp. 562. With Maps, Plates, Sections and Illustrations.

Price, \$3.00.

Sommary Report of the Operations of the Grological Corps, BY THE DiRECTOR.

Seuwys-Report on Boring Operations in the Souris River Valley.

Appendix 1-On the Lignite Tertiary Formation from the Souris River to the 108th Meridian, by Geo. M. Dawson.

A pPendix 2-Note by Principal Dawson on Fossil Plants collected by Dr. Selwyn in the Lignite Tertiary Formation of Roche Percé, Souris River.

Dawson (G. M.)-Report on an Exploration from Fort Simpson, on the Pacific Coast, to Edmonton, on the Saskatchewan, embracing a portion of the Northern part of British Columbia and the Peace River Country.

Appendix 1-List of Plants collected in the Northern part of British Columbia and the Peace River Country, 1879.

APPENDIX 2-Meteorological Observations in the Northern part of British Columbia, the Peace River District, and from Edmonton to Manitoba.

APPENDix 3-Note on Latitudes and Longitudes of the Region from the Pacific Coast to Edmonton.

Note on the Distribution of some of the more important Trees of British Columbia. (First printed in the Canadian Naturalist, Vol. IX, No. 9.)

BELL-Report on Hudson's Bay and some of the Lakes and Rivers lying to the West of it.

Appendix 1-List by J. F. Whiteares of Fossils collected by Dr. Bell in Manitobs, 1880.

Appendix 2-List by Prof. Macoun of Plants collected in 1880.

Appendix 3-List of Dr. J. L. LeConte of Coleoptera collected in 1880 in Manitoba, and between Lake Winnipeg and Hudson Bay.

Appendix 4-List of Land, Fresh-water and Marine Mollusca

ApPEndix 5-Analysis of the Waters of Hayes and Nelson Rivers, by Prof. Dittmar. 
Appendix 6-Seasonal or Periodic Events, York Factory.

Appendix 7-Tables showing Dates of the Opening and Closing of Hayes' River, at York Factory, from Records by Mr. Wm. Wood, Meteorologist, York Factory.

Appendix 8-Dates of the Arrivals of the Hudson Bay Company's Vessels, at York Factory, and of their Sailing for 93 years, from 1789 to 1880 , both inclusive.

Approdix 9-Seasonal or Periodic Erents, Moose Factory.

Apprendx 10-Dates of the Arrivals of the Budson Bay Company's Vessels at Moose Factory, and of their Sailings, for 147 years, from 1735 to 1880 , both inclusive.

Apprond 11-Statistics of the Weather, from Observations taken at York and Moose Factories by Messrs. Wm. Wood and J. R. Nason.

Ells-Report on Northern New Brunswick.

Furtorrb-Report of Surveys in Richmond, Inverness, Guysboro' and Antigonish, Nova Scotia.

Richardson-Report of a Geological Exploration of the Magdalen Islands, 1880-81.

Horrmans-Chemical Contributions to the Geology of Canada.

Report of Progress for 1880-81-82. Published Montreal, 1883. Eng-

lish and French. Large 8vo, pp. 223. With Maps, Plates, Sections and Illustrations.

Price, \$2.50.

This volume contains the following Reports :-

Introductory Reports by the Direotor.

Additions to the Library.

StuWYN-Geological Nomenclature and the Colouring and Notation of Geological Maps.

Index to Colours and Signs. Plate.

SinWYN-Notes on the Geology of the South-eastern portion of the Province of Quebec.

APPENDIX-Notes on the Microscopic Structure of some Rocks of the Quebec Group. By Frank D. Adams.

Dawson (G. M.)-Preliminary Report on the Geology of the Bow and Belly River Region, North-West Territory. With special reference to the Coal Deposits. 2 Plates. 1 Map.

Dawson (G.M.)-Notes on the more important Coal Seams of the Bow and Belly River District. 
Dawson (G. M.)-General Remarks on Coals and Lignite.

BELi-Report on the Geology of the Basin of Yoose River and adjacent Country.

BrLL-Report on the Geology of the Lake of the Woods and adjacent Country.

Appendix I-Catalogue, by Professor Maconn, of the Plants collected.

Appoxdix II-Lists, by Dr. J. L. Leconte, of Coleopt 3 ra from eleven Localities.

Ells-Report on Northern and Eastern New Brunswick and North side of the Bay of Chaleurs.

Ells-Report on the Geology of the Gaspe Peninsula.

Willimotr-Notes on some of the Mines in the Province of Quebec.

Hofryass-Chemical Contributions to the Geology of Canada.

SPECIAL REPORTS, \&c.

-Laurentian Limestones of North America. Reprinted with additions, from the Report of the Geological Survey for 1863-66. By T. Sterry Hunt, F.R.S., \&c. Published 187i. pp. 54.

Price, 25c.

- Descriptive Catalogue of a Collection of the Economic Minerals of Canada, and Notes on a Stratigraphical Collection of Rocks sent to the Philadelphia International Exhibition of 1876. Montreal, 1876. pp. 152.

Price, 25c.

-Exposition Universelle de 1876 a Paris, Catalogue des Minéraux économiques du Canada, avec Notes descriptives et explicatives. Par B. J. Harrington. Londres, 1878. pp. 134.

Price, 25c.

- Preliminary Note on the Geology of the Bow and Belly Rivers District, N.W. Territory, with Special Reference to the Coal Deposits. By George M. Dawson Published Montreal, 1882. pp. 19.

Price, 10c.

- Catalogue of Canadian Plants. Part I-Polypetalæ. By John Macoun,'M.A., F.L.S., F.R.S.O. Published Montreal, $1883 . \quad$ pp. 192.

Price, 25c.

- Comparative Vocabularies of the Indian Tribes of British Columbia, with a map illnstrating distribution. By W. Fraser Tolmie and George M. Dawson, D.S., A.R.S.M., F.G.S.C., \&c. Published Montreal. Large 8ro, pp. 131.

Price, 60c. 
- General Note on the Mines and Minerals of Economic value of British Columbia, with a List of Localities. By George M. Dawson, D. S.

Assoc., R.S.M , F.G.S., \&c. (Reprinted with additions and alterations from the Canadian Pacific Railway Report, 1877)

-Report on the Polyzoa of the Queen Charlotte Islands. By Rev.

Thos. Hincks, B.A., F.R S. Re-printed from the Annals and Magazine of Natural History, London, England, for December, 1882, June, 1883, and March, 1884.

\section{DESCRIPTIONS AND FIGURES OF CANADIAN ORGANIC REMAINS.}

Fossil Plants of the Devonian and Upper Sllurian Formations of Canada. By. Principal Dawson, F.R.S., LL.D. Published Montreal, 1871. Large 8vo, pp. 92.

Price, 50c.

Fossll Plants of the Erian (Devonian) and Upper Sllurian Formation of Canada. By Principal Dawson, C.M.G., LL.D., F.R.S. Published Montreal, 1882. Large 8vo, pp. 49. With fuur lithographed plates. Forming Part II. of the preceding.

Price, 50c.

This volume contains twenty lithographed plates illustrating the Pre-carboniferous Flora of the Dominion.

Fossil Plants of the Lower Carboniferous and Millstone Grit Formations of Canada. By Principal Dawson, F.R.S., LL.D. Published Montreal, 1873. With ten full-page lithographed plates. Large 8vo, pp. 47.

Price, 50c.

Paløozoic Fossils-Vor II-PArt I-Illustrated by 85 wood cuts and ten lithographed plates. By E. Billings. Published Montreal, 1874. Large 8vo, pp. 144.

Price, 50c.

Palæozoic Fossils-VoL. III-PART I-Illustrated by eight lithographic plates and four wood cuts. By J. F. Whiteaves. Published Montreal, 1884. Large 8vo. pp. 43.

Price, 50c.

Nesozolc Fossils-Vol. I., Part I.-On some Invertebrates from the Coal-bearing Rocks of the Queen Charlotte Islands, collected by Mr. James Richardson in 1872. By J. F. Whiteares. Published Montreal, 1876. With ten lithographed plates and a map showing localities of Fossils. Large 8vo, pp. 92.

Price, 50c. 
Mesozoic Fossils-Vol. I., Part II.-On the Fossils of the Oretaceous Rocks of Vancouver and adjacent Islands in the Strait of Georgia. By J. F. Whiteares. Published Montreal, 1879. With ten lithographed plates. Large 8vo, pp. 98.

Price, 50c.

Mesozoic Fossils-Vol. I., PART III-On the Fossils of the Coal Bearing Deposits of the Queen Charlotte Islands, collected by Dr. G. M. Dawson in 1878. By J. F. Whiteares. Published, Montreal, 1884. With twelve lithographed plates. Large 8vo, pp. 72.

Price, 500.

*Contributions to the Micro-Palæontology of the Cambro-Silurian Rocks of Canada. By Arthur H. Foord. Published Ottawa, 1883. pp. 26. Plates, 7.

Price, 50c.

MAPS.

Report of Progress, 1871-72.

* Map showing the position of the Coal Fields of Nanaimo and Comox, Vancouver Island. Scale 10 miles to 1 inch.

Price, 20c.

Map of the Township of Marmora showing the position of the Gold

Mines. Scale 1 mile to an inch.

Report of Progress, 1872-73.

* Plan of the Acadia 1ron Yines, and Profile on the Line of Ore. Scale 400 yards to an inch.

Price, 30c

Map of a part of the Strait of Georgia and of Vancouver Island, showing a portion of the Comox Coal Field and the distribution of the Cretaceous Coal-bearing Rocks. Scale 2 miles to 1 inch.

Plan of the Dalhousie Iron Mine, Lanark County, Ontario.

Report of Progress, 1873-74.

Sketch Survey of the Saskatchewan River from Rocky Mountain House to Cumberland Lake. Scale 16 miles to 1 inch.

*Plan of North Burgess, showing position of Apatite Openings. Scale $\frac{1}{2}$ a mile to 1 inch.

Price, 20c.

Index map showing the position of the Springhill Coal Field. Scale 1 mile to an inch.

Report of Progress, 1874-75.

Map showing the distribution of the Iron Ores of Carleton County, New Brunswick. 
-Shaded Geological Map of Lanark County and parts of Ronfrew and Leeds, Ontario. Scale 4 miles to 1 inch.

Price, 25c.

* Co'oured Geological Map of the Cape Dauphin District, Cape Breton, Nora Scutia. Scale 4 inches to a mile.

Price, 15c.

- Coloured Geological Map of the Sydney Coal Field, Cape Breton, Nova Scotia. Scale 1 inch to a mile.

Report of Progres3, 1875-78.

Price, 25c.

- Sketch Survey of Route from Quesnel Month by Stewart and McLeod Lakes to the Junction of Smoky River and Peace River. Scale 6 miles to 1 inch.

Price, 25c.

"Sketch-Map of Route from the Forks of Peace and Smoky Rivers to

Carlton House, Saskatchewan River. Scale 40 miles to an inch.

Price, $15 c$.

- Coloured Geological Map of the Sydney Coal Fields, Cape Breton, Nova Scotia. Scale 1 inch to a mile.

Report of Progress, 1876-77.

Price, 25c.

* Coloured Geological Map of portion of British Oolumbia between the

Fraser River and the Coast Rınge. Scale 8 miles to 1 inch.

Price, 25c.

* Coloured Geological Map of a portion of British Columbia, showing the Coal Fields of Comox, Nanaimo and Cowitchin on Vancouver and adjacent Islands, and the distribution of the Cretaceous Coal-bearing Rocks; also the Tertiary Rocks of Sooke and Burrard Inlets. Scale 4 miles to 1 inch.

Price, 25c.

*Coluured Map showing the distribution of the Phosphate of Lime Rocks and the position of the most important Mines in Ottawa County, Quebec. Scale 4 miles to an inch.

Price, 25c.

- Coloured Geological Map of the Lower Carboniferous Rocks of Albert and Westmoreland Counties, New Brunswick, showing the distribution of the Albert Shales. Scale 1 inch to a mile.

Price, 20c.

* Coloured Geological Map of part of CapeBreton, Nova Scotia. Scale 1 inch to a mile.

Price, 25c.

Report of Progress 1877-78.

Map of part of the East Coast of Hudson's Bay, to illustrate Dr. Bell's

Report C. Scale 4 miles to 1 inch. 
Map of Lake Winnipeg. Scale 8 miles to 1 inch.

Map of Nelson River and the Boat Route between Lake Winnipeg, including an enlarged Plan of the Mouth of Hayes' River and vicinity of York

Factory. First, scale 8 miles to 1 inch; second, scale 1 mile to 1 inch.

Geological Map of part of Cape Breton, Nova Scotia. Hugh Fletcher.

Report F. Scale 1 mile to 1 inch.

Geological Map of a portion of the Southern Interior of British Columbia.

G. M. Dawson. Report B. Scale 8 miles to 1 inch.

- Report of Progress for 1878-79.

Map of the Queen Charlotte Islands. 'G. M. Dawson. Report B. Scale 8 miles to 1 inch.

Plans of Harboura, Queen Charlotte Islands. G. M. Dawson. Report B. Scale 2 nautical miles to 1 inch.

Geological Map of Skidegate Inlet, Queen Charlotte Islands. G. M. Dawson. Report B. Scale 1 mile to $\frac{1}{2} f$ inch.

Map of Island and God's Lakes, and the connecting waters to Oxford Lake, Robert Bell. Report C. Scale 4 miles to 1 inch.

Three Sheets Geological Map of Southern New Brunswick, to illustrate the Annual Reports of Messrs. Bailey, Matthew and Ells, up to 1878. Scale 4 miles to 1 inch.

Report of Progress for 1879-80.

Map illustrating the distribution of some of the more important Trees in British Columbia. G. M. Dawson. Report B. Scale 50 miles to 1 inch.

Map of part of British Columbia and the North-West Territory, from the Pacific Ocean to Fort Edmonton (three sheets). In portfolio, accompanying report. G. M. Dawson. Scale 8 miles to 1 inch.

Map showing the General Northern Limits of the Principal Forest Trees of the Dominion of Canada, east of the Rocky Mountains. In portfolio, accompanying report. Robert Bell. Scale 80 miles to 1 inch.

Report of Progress for 1880-81-82.

Index Map of Coal and Lignite Outcrop in the Bow $\approx n d$ Belly River District. G. M. Dawson. Report B. Scale 10 miles to 1 inch.

Five Sheets Geological Map of Northern and Eastern New Brunswick, with a portion of the Gaspé Peninsula. R. W. Ells. Scale 4 miles to 1 inch.

Map showing approximately the Geology of the Basin of Moose River. Robert Bell. To illustrate Reports from 1875-77 and 1881. Scale 8 miles to $1 \mathrm{inch}$. 
Plan of Moose River from the neighbourhood of Moose Factory to James' Bay. Robert Bell. Report O. Scale 2 miles to 1 inch.

Geological Map of the Lake of the Woods and adjacent country. Robert Bell. Report C. Scale 4 miles to 1 inch.

A Topographical Map of the Eastern Townships (in four sheets) embracing an area of 26,121 square miles, from St. Jerôme and Lake of the Two Mountains, on the west, to New Hampshire and Maine Boundary, on the east, and from latitude $45^{\circ}$ to $47^{\circ} 50^{\prime}$ north. Scale 4 miles to an inch.

Price, $\$ 4.00$.

\section{MUSEUM AND LIBRARY.}

The Geological and Natural History Museum and Headquarters of the Survey were, in accordance with an Act of the Dominion Parliament, 40 Vic., cap. 9, sec. 7, removed from Montreal to Ottawa, snd are now established in a three-story stone building on the corner of Sussex and George streets.

The large increase of visitors to the Nuseum, since its removal from Montreal, fully justifies the action of the Government in transferring it to the Capital. The largest number of names entered in the register of visitors for any one year, at Montreal, was 1,652, and this number, in 1880, was reduced to 1,183; whereas, at Ottawa, at the end of the first year, there were 9,549 names registered; at the end of the second yeąr 10,806, and at the end of the third 12,325 .

The ground floor contains offices, library and laboratory. On the first floor there are two rooms devoted to museum purposes-the larger one, 103 feet long by 24 feet wide, contains upwards of 4,000 geological and mineralogical specimens, arranged in cases to illustrate the economic and scientific geology of the Dominion. The specimens are labeled, showing the localities from which they were obtained, and the formations to which they belong. The economic collection is arranged under the following heads :-

I. Metals and their Ores.

II. Fossil Fuel.

IIl. Minerals applicable to certain Ohemical Manufactures, and their Products (see-also under IV).

IV. Mineral Manures (see also under III).

V. Mineral Pigments and Detergents.

VI. Salt, Brines and Mineral Waters.

VII. Materials applicable to Common and Decorative Construction. 
VIII. Refractory Materials, Pottery Clays and Pottery.

IX. Materials for Grinding and Polishing.

X. Minerals applicable to the Fine Arts and to Jewelry.

In the smaller room on the same floor ( $22 \mathrm{ft} .6 \mathrm{in}$. by $17 \mathrm{ft} .8 \mathrm{in}$.) there is a small collection of foreign minerals which, as opportunities occur, will be augmented; also, a collection of specimens of native woods.

The rooms on the second floor are of the same dimensions as those on the first floor. The larger one contains upwards of 11,000 specimens of Canadian fossils, representing over 3,000 species; also, about 6,000 species of shells comprising upwards of 14,000 specimens, most of which are exotic.

In the smaller room on this floor there is a small ethnological collection, chiefly from the Indians of the Pacific Coast. A larger collection of Indian relics, mainly from Ontario, was recently acquired. It contains upward s of 3,500 specimens, but owing to want of available space they cannot, at present, be exhibited.

The Museum possesses an Herbarium containing upwards of 7,000 specimens of the North American flora, including a nearly complete series of plants indigenous to Canada.

It contains also the commencement of a collection of native mammals and birds which, however, includes a few very rare Arctic.and NorthWestern species. There are, at present, 21 species of mammals and about 70 species of birds, represented by 140 specimens

In the Library there are upwards of 5,500 volumes, comprising standard works of reference on geology, mineralogy, metallurgy, chemistry and natural history. Persons desiring to consult any volume can do so, by applying to the Librarian.

The Museum is open to visitors from $10 \mathrm{a}$ m. to 4 p.m. Admission free.

OttaWa, March, 1884. 
ADDITIONAL PUBLICATIONS ISSUED BY THE GEOLOGICAL AND NATURAL HISTORY SURVEY OF CANADA, SINCE THE LIST OF 3884 WAS PRINTED.

Report Progress for 1882-83-84. Published Montreal, 1885. English and French. Large 8vo., pp. 786. With Maps, Plates, Sectious and Illustrations.

This volume contains the following Reports :Price, $\$ 3.25$.

Selwyx - Summary Reports by the Director.

Additions to the Library.

Bauersan-Report on the Geology of the Country near the Fortyninth Para!lel of North Latitude, West of the Rocky Mountains, from Observations made in 1859-61.

Dawson-Report on the Region in the vicinity of Bow and Belly Rivers, N.W.T.

Appendix I-List of Elevations.

Appendix II-Blackfoot Indian Names of Places.

APpexdix III-Analyses of Ironstones.

BELL-Report on part of the Basin of Athabasca River, N.W.T.

LaFLAMME-Report of Geological Observations in the Saguenay Region.

BELL - Observations on Labrador Coast, Hudson Strait and Bay.

ElLS-Report on Explorations and Surveys in the interior of Gaspé Peninsula and Prince Edward Island.

Low - Report on Explorations and Surveys in the interior of Gaspe Peninsula.

BAILEY-Report of Explorations and Surveys in portions of York and Carleton Counties, N.B.

Chalmers-Report on the Surface Geology of Western New Brunswick, with special reference to the area included in York and Carleton Counties.

Fletcher-Report on the Geology of Northern Cape Breto ?.

Torrance-Report on Apatite deposits, Ottawa County, Quebec.

Coste-Report on the Gold Mines of the Lake of the Woods.

WiLimotr-Report of Observations in 1883 on Mines and Minerals, in Ontario, Quebec and Nova Scotia. 
HofrmanN-Analyses of Coals and Lignites of the North-West Terri-. tory.

Hoffmank - Chemical Contributions to the Geology of Canada from the Laboratory of the Survey.

Summary Report of the Oporations of the Geological and Natural History Survey, to 31st December, 1885, being Part III., A nnual Report of the Department of the Interior, 1885.

Price, 15c:

Annual Report, 1885. Published Montreal, 1886. English and French. Large 8ro., pp. 834. With Maps, Plates, Sections and Illustrations.

Price, \$2.0 .

This volume contains the following Reports, which are also published separately :-

(A) Selwyn-Summary Rejort by the Director for years 1884 and 1885.

Price, 25c.

(B) Dawson - Preliminary Report on the Physical and Geological Features of that portion of the Rocky Mountains between Latitudes $49^{\circ}$ and $51^{\circ} 30^{\prime}$. With Maps.

Price, 25c.

(C) McConneld-On the Cypress Hills, Wood Mountain and adjacent country. With Maps.

Price, 25c.

(CC) Lawson-On the Geology of the Lake of the Woods Region, with special reference to the Keewatin (Huronian?) Belt of the Arch $\ltimes$ an Rocks. With Map.

Price, 25c.

(D) Low-Report of the Mistassini Expedition, 1884-85. With Map. Appendix I-List of Birds collected on Lake Mistassini, by Jas. M. Macoun.

Appendix II-List of Plants collected at Lake Mistassini, \&c., by Jas. M. Macoun.

ApPendix III-Meteorological Observations.

Price, $15 \mathrm{c}$

(DD) Belu-Obserrations on the Geology, Zoology and Botany of Hudson's Strait and Bay. With Map of Ottawa Islands.

Appendix I-Lists by Prof. Macoun, of Plan's collected in Newfoundland.

A PPEnolx II-Partial List of Insects collected in 1885, by Dr. R. Bell. Price, $15 \mathrm{c}$. 
(E) ElLs-On the Geological Formations of Eastern Albert and Westmoreland Counties, New Brunswick, and of portions of Cumberland and Colchester Counties, Nova Scotia. With Map.

Price, 20c.

(G) BAlLEY - Explorations and Surveys in portions of the Counties of Carleton, Victoria, York and Northumberland, New Brunswick. With Map.

Price, 20c.

(GG) Cualsers-Preliminary Report on the Surface Geology of New Brunswick.

Price, 20c.

(K) CostE-Observations on Mining Laws and Mining in Canada, with suggestions for the better development of the Mineral Resonices of the Dominion.

P'rice, $15 \mathrm{c}$.

(M) Hoffmasw-Chemical Contributions to the Geology of Canada, from the Laboratory of the Survey

Price, 15c.

MAPS.

The following is a List of Maps accompanying the foregoing Reports :-

Report of Progress, $1832-84$.

1. Geological Map of the Region in the vicinity of Bow and Belly Rivers. Seale 8 miles to 1 inch.

Price, $10 \mathrm{c}$.

2. Map showing Wooded and Prairie Districts, \&c, in the Region in the vicinity of Bow and Belly Rivers. Scale 8 miles to 1 inch.

Price, 10c.

3. Map of part Athabasca River. Scale 8 miles to 1 inch.

Price, 10c.

4. Ten Sheets Geological Mlap of New Brunswick, Quebec and Prince Edward Island Scale 4 miles to 1 inch. Numbers $1 \mathrm{~N}$.W., New Brunswick; $5 \mathrm{~S} \mathrm{~W}$, New Brunswick and Prince Edward Island; $5 \mathrm{~N} \mathrm{~W}$, Prince Edward Island; 5 S.E , Prince Edward Island; 3 N E. ; 3 N.W. ; 6 N.W. ; 7 S.W.; 15 S.E. ; 15 S.W., Quebec. $\quad$ Price, 10c. per sheet.

5. Twenty-four Sheets Geological Map of Cape Breton. Scale 1 mile to an inch. These sheets are numbered 1 to 24 . Nos. 22 and 24 embrace adjacent parts of Nova Scotia.

Price, 10c. per sheet.

6. Panoramic View of Notre Dame Mountains, Gaspé, to illustrate Report by A. P. Low.

Price, 10c. 
Annual Report, 1885.

1. Reconnaissance Map of a portion of the Rocky Mountains between Latitudes $49^{\circ}$ and $51^{\circ} 30^{\prime}$. Geologically coloured.

Price, 10c.

2. Geological Map of part of the Cascade Coal Basin, Rocky Mountains.

Price, 10c.

3. Geological and Topographical Mrp of the Cypress Hills, Wood Mountain and adjacent country.

Price, 10c.

4. Map showing Wooded Tracts and character of Surface of the Cypress Hills, Wood Mountain and aljacent country.

Price, 10c.

5. Geological Map of the Northern part of the Lake of the Woods and adjacent country.

Price, 10c.

6. Map of Lake Mistassini, with Geological Boundarıes.

7. Chart of the Ottawa Islands, Hudson Bay.

8. Sheet No. 4 N.W., New Brunswick and Nova Scotia.

9. Sheet No. 2 S.W., New Brunswick.

Price, 10c.

Price, 10c.

Price, 10c.

Price, 10c.

\section{SPECIAL REPORTS.}

Catalogue of Canadian Plants. Part 2. Gamopetalæ. By John Macoun, M.A., F.L.S., F.I.S.C. Published Montreal, 1884. pp. 398.

ce, $:-5 \mathrm{c}$.

Contributions to Canadian Palæontology. Vol. 1, Part I-Report on the Invertebrata of the I.aramie and Cretaceous Rocks of the vicinity of the Bow and Belly Rivers and adjacent localities, in the North-west Territory. By J. F. Whiteares, F.G.S., F.R.S.C., \&c. Published Montreal, 1885. Large 8ro., pp. 89. Illustrated by eleven lithographic plates.

Price, 50c.

Descriptive Catalogue of a Collection of the Economic Minerals of Canada. By the Geological Corps (Colonial and Indian Exhibition, London, 1836). Published London, 1886. pp. 172.

Price, 15c.

Catalogue of Canadian Plants. Part 3. Apetalæ. By John Macoun, M.A., F.I.S., F.R.S.C., Published Montreal, 1886. pp. 228.

Price, $25 \mathrm{c}$. 

